\title{
A comparative analysis of the quality of concrete blocks produced from coconut fibre, oil palm empty fruit bunch, and rice husk as filler material
}

\author{
Mohammad Lutfi ${ }^{1,}$, Muh Yamin ${ }^{2}$, Mujibu Rahman ${ }^{2}$, and Elisa Ginsel Popang ${ }^{2}$ \\ ${ }^{1}$ Department of Petroleum Engineering, STT MIGAS, Balikpapan, 76127, Indonesia \\ ${ }^{2}$ State Agricultural Polytechnic of Samarinda, 75131, Indonesia
}

\begin{abstract}
The accumulation of coconut fibre $(\mathrm{CF})$, oil palm empty fruit bunch (OPEFB), and rice husks (RH) every year can reduce the fertility of soil and water absorption, and causes water acidification. Waste utilization as a filler material of concrete blocks was discussed in this research. Experimental design was used by comparing the quality of concrete blocks based on 36 specimens with varied compositions of waste $(1 \%, 2 \%, 3 \%$, and $4 \%$ by dry weight of total sand) and 3 specimens $(0 \%)$ as control specimens with 3 replications for each composition. The quality of paving blocks was determined based on the testing of water absorption, porosity, compressive strength, and density. The results revealed that the quality of concrete blocks with the composition of CF (1\% and 2\%), OPEFB (1\% and $2 \%$ ), and $\mathrm{RH}(1 \%)$ meet the requirements of SNI 03-0691-1996 criteria in category B for parking paver and the maximum composition of each waste materials (3\% and 4\%) still comply SNI 15-2094-2000 in class 100 and 150 for the block walls. Statistical analysis revealed that the best treatments for compressive strength was RH (1\%) and for water absorption it was RH (2\%) and CF (4\%).
\end{abstract}

\section{Introduction}

The waste produced from agricultural and industrial production activities such as empty palm fruit bunch (OPEFB), rice husk (RH), and coconut fibre (CF) are the lignocellulosic materials which causes environmental pollution problems.

OPEFB is the solid waste produced from the palm oil industry. In Indonesia, the volume of crude palm oil (CPO) is approximately 28 million tons per year [1]. The increase of the production is in line with the increase of OPEFB as its waste. It causes environmental hazards from the landfill process [2]. The remainder of the oil palm significantly affected the soil's physical and chemical properties, and nutrient content $[3,4]$.

\footnotetext{
* Corresponding author: lutfi_plhld@yahoo.co.id
} 
In the majority of rice producing countries, $\mathrm{RH}$ is burnt in open air or is sent to a land fill [5]. However, both methods create enormous $\mathrm{CO}_{2}$ emission into the atmosphere. This causes the environmental problem of disposal due to its abundance.

$\mathrm{CH}$ is the mesocarp of coconut and a coconut consists of $33-35 \%$ husk [6]. The natural fibre extracted from $\mathrm{CH}$ is $\mathrm{CF}$. It has led to the emergence of the coir industry. The retting process causes extensive damage to the Kayals of Kerala and the aquatic habitats along the southwest coast of India due to oxygen depletion and high concentrations of hydrogen sulphide $[7,8]$.

One of the efforts to overcome this problem is by using the waste as a filler material for concrete blocks. This effort is in line with the increasing demand of the building materials that had come into the concern of the public and related industries. In Malaysia, the agro-waste is generated from agricultural sources such as $\mathrm{RH}$, jute fibre (JF), and $\mathrm{CH}$ [9]. This agro-waste can be remade into sustainable building materials. Reuse of such agrowaste does not only overcome the pollution to the environment and shortage of building materials but also the disposal problem of agro-waste and achieves the objective of sustainable development.

The research related to the durability of concrete has been conducted by many researchers to minimize the negative ecological impact [10-18]. This research proposes to utilize OPEFB, RH, and CF without combustion process to reduce air pollution which is the trigger of global warming [19].

According to the background, a comparative study of the quality of concrete blocks produced from OPEFB, RH, and CF as a filler material based on the Indonesian National Standard (SNI) is discussed in this paper. The results are expected to be a recommendation for areas that have less sand, but have abundant OPEFB, CF, and RH, so it can help the areas toward a sustainable development.

\section{Method}

\subsection{Materials}

The waste was collected from different places, namely: OPEFB was obtained from PTPN XIII Semuntai, RH obtained from the rice mill at Loa Janan, and CF was obtained from Samarinda. River sand was obtained from Mahakam river and the water used in this experiment was clean tap water free from impurities capable of undermining the chemical reaction of cement with the water. Portland Pozzolan Cement (Gresik Cement) in a wellprotected condition from dampness was used in this research.

The waste material was cleaned and selected, then, mineralization process was conducted before the mixing process to remove lignin, cellulose, and another compound which prevents the stickiness and hardening of cement for concrete mixtures through soaking and drying under the sun light directly.

\subsection{Experimental design}

\subsubsection{Design of concrete mixes}

The mold was made with a size of $22 \mathrm{~cm}$ in length, $8 \mathrm{~cm}$ in width, and $6 \mathrm{~cm}$ in thickness (Fig. 1). The number of specimens with composition of waste materials were 36 and 3 specimens without waste materials as specimen control. 


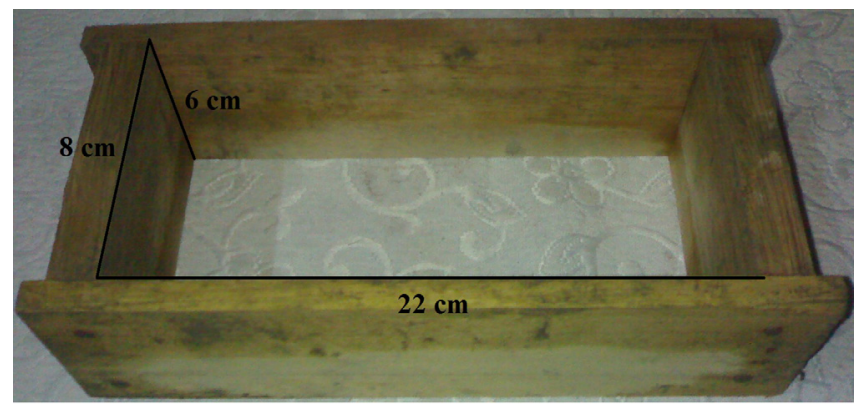

Fig. 1. The mold size of concrete blocks

The concrete blocks were produced in five different treatments with 3 replications for each treatment (3 specimens for each treatment). Design of concrete mixes are as follows:

Table 1. Design of concrete mixes for each treatment.

\begin{tabular}{|c|c|c|c|c|c|}
\hline Treatment & $\begin{array}{c}\text { Waste } \\
(\% \text { of sand) }\end{array}$ & $\begin{array}{c}\text { Waste } \\
(\mathbf{k g})\end{array}$ & $\begin{array}{c}\text { Cement } \\
(\mathbf{k g})\end{array}$ & $\begin{array}{c}\text { Sand } \\
(\mathbf{k g})\end{array}$ & $\begin{array}{c}\text { Water } \\
(\mathbf{k g})\end{array}$ \\
\hline $\begin{array}{c}\text { Treatment 1 } \\
\text { (control specimen) }\end{array}$ & 0 & 0 & 0.555 & 2.775 & 0.37 \\
\hline Treatment 2 & 1 & 0.028 & 0.555 & 2.747 & 0.37 \\
\hline Treatment 3 & 2 & 0.056 & 0.555 & 2.72 & 0.37 \\
\hline Treatment 4 & 3 & 0.083 & 0.555 & 2.692 & 0.37 \\
\hline Treatment 5 & 4 & 0.111 & 0.555 & 2.664 & 0.37 \\
\hline
\end{tabular}

\subsubsection{Casting, curing, and testing}

The casting was conducted by hand mixing for each treatment without vibration process. After the specimens were removed from the molds, curing was performed until it reaches a constant weight at an age of 28 days. During the curing process, loss of water from the concrete blocks was prevented as much as possible.

The quality and characteristics of concrete blocks was determined by observing the physical appearance of specimens and performing water absorption and compressive strength tests at the laboratory of civil engineering (State Polytechnic of Samarinda) based on the national standardization agency of Indonesia on the SNI 03-0691-1996 [20] and SNI 15-2094-2000 [21] criteria.

\subsubsection{Analysis}

The quality of concrete blocks among the specimens with waste materials and the control specimen were analyzed based on the average values (compressive strength, density, water absorption, and porosity) of each treatment to have a quick overview.

Analysis of variance was conducted using completely randomized designs to investigate the effect of treatments on the quality of concrete blocks. Furthermore, in cases where there is a significant difference between means, then LSD analysis was used to determine which treatments are the best among them based on [20] and [21] criteria and the concept of waste management approach. LSD must not be applied unless the F-test indicates that significant differences between means were present. 
The correlation between the composition of waste materials on the compressive strength and water absorption were described using linear regression analysis. The relationship level is stated in numbers, wherein a larger number shows a stronger relationship. The guidance of the correlation coefficient interpretation are as follows: $0.000-0.199$ (very weak), 0.200 -0.399 (weak), $0.400-0.599$ (inconclusive), $0.600-0.799$ (strong), and $0.800-1.000$ (very strong) [22].

\section{Results and discussions}

\subsection{Visual appearance}

The whole specimens that were produced revealed that the visual appearance meet the requirement of [20, 21]. Fig. 2 shows that the concrete blocks produced from CF, OPEFB, and $\mathrm{RH}$ respectively are not cracked and defective, also, the corners are not easily damaged by finger strength.

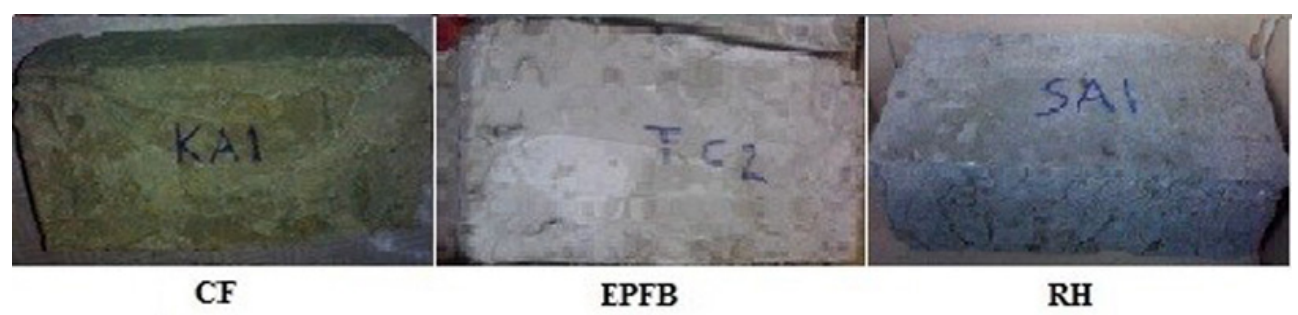

Fig. 2. Visual appearance of concrete blocks produced from $\mathrm{CF}, \mathrm{OPEFB}$, and RH.

\subsection{Water absorption and porosity}

According to Fig. 3(a), the average values of water absorption level of the concrete blocks with filler materials from OPEFB, CF, and $\mathrm{RH}$ can be described as follows:

a. Treatment 3 and treatment 4 with the composition of CF $(30 \%$ and $40 \%)$ meet the requirements of [20] criteria in category $\mathrm{A}$ and [21]. The treatment 1 and treatment 2 with the composition of OPEFB (10\% and $20 \%)$ comply to [20] criteria in category B and SNI [21].

b. Treatment 2 and treatment 4 with the composition of RH $(20 \%$ and $40 \%)$ meet the requirements of [20] criteria in category $\mathrm{A}$, treatment 1 with the composition of RH $(10 \%)$ in category $\mathrm{B}$, and treatment 3 with composition of $\mathrm{RH}(30 \%)$ in category $\mathrm{C}$. All treatments comply with [21].

c. Treatment 1 with the composition of OPEFB (10\%) meet the requirements of [20] criteria in category B and SNI 15-2094-2000. The treatment 2 to treatment 4 with the composition of OPEFB (20\%, 30\%, and 40\%) comply with SNI 03-0691-1996 criteria in category $\mathrm{A}$ and $[21]$.

The base value (3.60) is the average value of water absorption of control specimens with no waste materials (treatment 1). In general, water absorption of specimens produced from waste are better than control specimens.

According to Fig. 3(b), the decrease in porosity is proportional to the addition of waste materials, except for RH. Further research needs to be conducted at composition of 5\%, $6 \%, 7 \%$ and so on. Probably, at the particular composition, the porosity and water absorption will increase gradually in line with the addition of waste materials. 


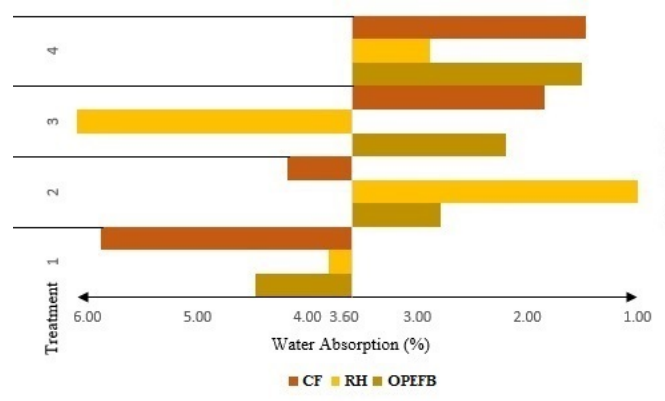

(a)

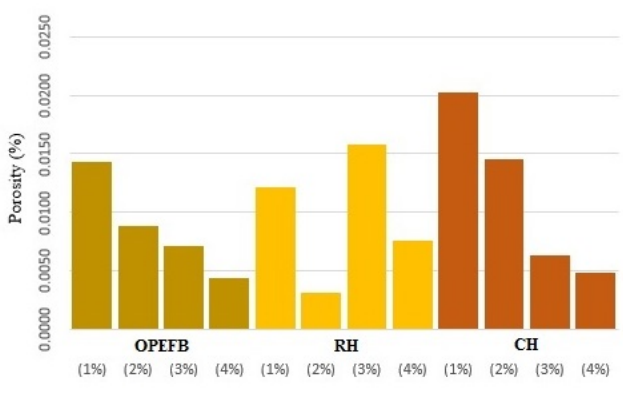

(b)

Fig. 3. Comparison of (a) water absorption and (b) porosity among $\mathrm{CF}, \mathrm{RH}$, and OPEFB

One of the causes of the variation of porosity for RH is that the husks used was not crushed first, but mixed into the mixture directly, it will cause the increasing of water absorption and porosity for treatment 1 and treatment 3. Whereas in treatment 2 and treatment 4 , the husks was crushed before mixing, so that the water absorption is low.

\subsection{Compressive strength and density}

According to Fig. 4(a), the average values of the compressive strength of concrete blocks with filler material from OPEFB, CF, and RH can be described as follows:

a. Treatment 1 and treatment 2 with the composition of OPEFB (10\% and 20\%) meet the requirements of [20] criteria in category $B$ and [21] in class 150 . Treatment 3 and treatment 4 with the composition of OPEFB (20\% and 30\%) comply [20] criteria in category $\mathrm{C}$ and [21] in class 150 .

b. Treatment 1 and treatment 2 with the composition of CF $(10 \%$ and $20 \%)$ meet the requirements of [20] criteria in category B and [20] in class 150. Treatment 3 and treatment 4 with the composition of $\mathrm{CF}$ (30\% and 40\%) comply with [20] criteria in category $\mathrm{C}$ and [21] in class 100 for treatment 3 and class 150 for treatment 4 .

c. Treatment 1 and treatment 3 with the composition of $\mathrm{RH}(10 \%$ and $30 \%)$ meet the requirements of [20] criteria in category $\mathrm{B}$, treatment 2 with composition of $20 \%$ in category $\mathrm{C}$, and treatment 4 with composition of $40 \%$ in category D. The whole treatments comply with [21] in class 150 except treatment 4 which is included in class 100.

Base value (31.67) is the average value of the compressive strength of the control specimens without waste materials. The compressive strength of the whole treatments have average values below the control specimen. The adhesion process under the influence of the gravitational field [23] between cement and aggregate increases the compressive strength, whereas the cohesion process between aggregate decreases the compressive strength. 


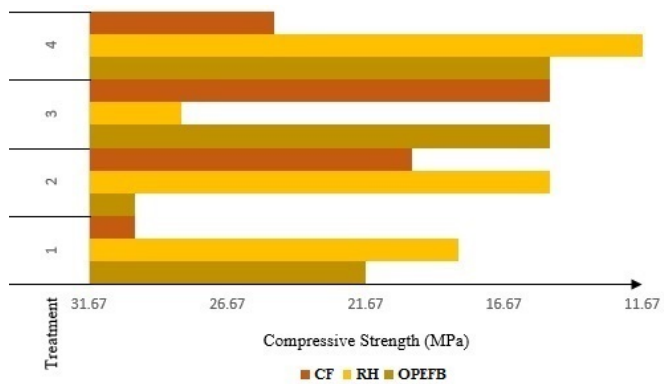

(a)

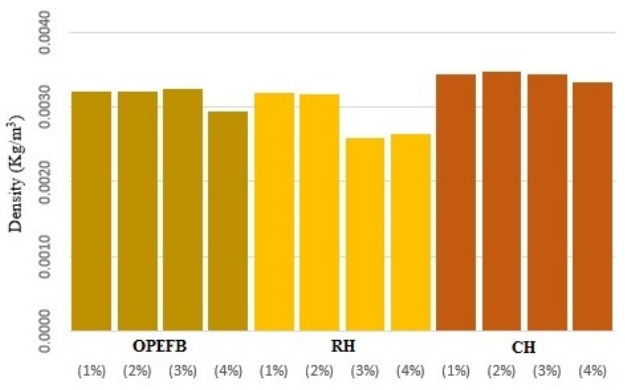

(b)

Fig. 4. Comparison of (a) the compressive strength and (b) density among CF, RH, and OPEFB

The variation of compressive strength values for each replication at the same composition is caused by the compacting process that was conducted by hand without the vibration process which has led to the nonhomogeneous problem during the casting process.

The addition of waste materials is decreasing the density of specimens, it causes the compressive strength to also decrease due to the density of the waste materials to be less than the density of sand. Fig. 4(b) depicts the decrease in density due to the addition of waste materials.

\subsection{Completely randomized designs}

Analysis of variance by means of completely randomized designs revealed that the effect of treatments on the water absorption and compressive strength of concrete blocks can be described as follows respectively:

a. There are no significant differences of OPEFB composition variation on the water absorption with calculated $\mathrm{F}(2.386)<$ table $\mathrm{F}$ (4.066) and the compressive strength with calculated $\mathrm{F}(2.355)<$ table $\mathrm{F}(4.066)$ for a significance level of $5 \%(\alpha=5 \%)$.

b. There are significant differences of RH composition variation on the water absorption with calculated F (32.023) > table F (7.591) for $\alpha=1 \%$ and also for RH composition variation on the compressive strength with calculated F (4.148) $>$ table F (4.066) for $\alpha=$ $5 \%$.

c. There is a significant difference of $\mathrm{CF}$ composition variation on the water absorption with calculated $\mathrm{F}(33.644)>$ table $\mathrm{F}(7.591)$ for $\alpha=1 \%$. Whereas there is no significant difference of $\mathrm{CF}$ composition variation on the compressive strength with calculated $\mathrm{F}$ $(0.937)<$ table F (4.066) for $\alpha=5 \%$.

\subsection{Least significance different (LSD) analysis}

LSD calculations are used based on the results of completely randomized designs, if the results revealed that there is a significant difference between the means of waste composition on the water absorption and compressive strength, then LSD can be used, and vice versa.

According to the compressive strength on [20], LSD analysis revealed that treatments of $\mathrm{RH}$ for composition of waste $1 \%, 2 \%$, and $3 \%$ are good treatments. Treatment for compositions of $1 \%$ are included in category $\mathrm{B}$, while for compositions of $2 \%$ and $3 \%$ are included in category $\mathrm{C}$.

The best treatment for $\mathrm{RH}$ with composition of waste of $2 \%$ and treatments of CF with composition of $3 \%$ and $4 \%$ are included in quality $\mathrm{A}$ based on water absorption level on 
[20]. In context of waste management, the more waste that can be recycled, the more amount of waste can be reduced, therefore, the best treatment for $\mathrm{CF}$ is with composition of $4 \%$.

\subsection{Correlation}

A very strong relationship was indicated by a high correlation coefficient between the composition of OPEFB and CF on water absorption, $\mathrm{R}^{2}=0.9337$ with regression equation of $y=-0.949 x+5.1125$ for OPEFB and $\mathrm{R}^{2}=0.9399$ with regression equation of $y=-$ $1.5604 x+7.2445$ for CF respectively. Whereas a very weak relationship can be seen between composition of $\mathrm{RH}$ and water absorption $\left(\mathrm{R}^{2}=0.0198\right.$ with regression equation is $\mathrm{y}=0.023 \mathrm{x}+2.8713)$.

An inconclusive relationship was indicated between the composition of OPEFB and CF on the compressive strength, $\mathrm{R}^{2}=0.4027$ with regression equation of $y=-3.5 x+29.167$ for OPEFB and $\mathrm{R}^{2}=0.5729$ with regression equation of $y=-2.1667 x+23.333$ for $\mathrm{CF}$ respectively. Whereas the very weak relationship can be seen between the composition of $\mathrm{RH}$ and the compressive strength $\left(\mathrm{R}^{2}=0.0143\right.$ with regression equation of $y=-0.0667 x+$ 20).

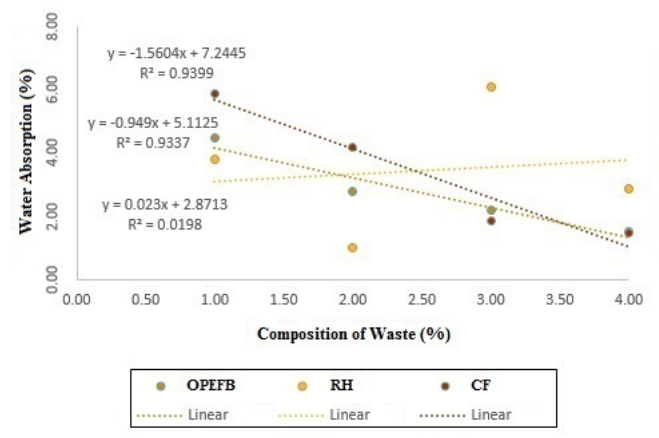

(a)

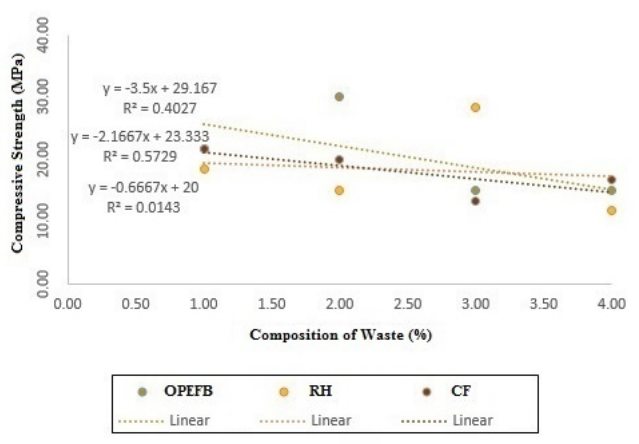

(b)

Fig. 5. Correlation of (a) composition of waste and water absorption and (b) composition of waste and compressive strength

The obtained regression equation is valid for the used data in this research. The relationship between the composition of waste on the compressive strength and water absorption will be varied based on the accuracy of the experimental design, therefore, this equation needs to be proved using a better method for further research at the same composition of waste with the same composition of mixes.

\section{Conclusions}

The results revealed that the quality of concrete blocks with the composition of CF $(1 \%$ and $2 \%$ ), OPEFB ( $1 \%$ and $2 \%$ ), and RH (1\%) meet the requirements of [20] criteria in category $\mathrm{B}$ for parking paver and the maximum composition of each waste (3\% and $4 \%$ ) still comply with [21] criteria in class 100 and 150 for the block walls.

According to the completely randomized designs and least significance difference calculations, the best treatment for the compressive strength test is RH with composition of waste $1 \%$ included in category B on [20] criteria and the best treatment based on the water absorption test were RH with composition of waste $2 \%$ and $\mathrm{CF}$ with composition of waste $4 \%$ included in category A. 
Linear regression analysis revealed a very strong and inconclusive relationship indicated between the composition of OPEFB and CF on water absorption and compressive strength tests respectively. Whereas the very weak relationship of $\mathrm{RH}$ to both tests revealed that treatments 1 and 3 need to be repeated by crushing the husk before the mixing process.

The results of this research need to be compared to the other experimental designs at the same composition of each waste material (especially for RH treatments) with a better method using machines and the technology to reduce the content of lignin and cellulose and other substances without burning waste materials to obtain the silica contained in the charcoal. The abrasion and resistance to sodium sulphate tests also need to be conducted to describe comprehensively the quality of concrete blocks based on [20] criteria.

Financial support from the Regional Goverment Budget, East Kalimantan Regional Goverment of Indonesia for this work is gratefully acknowledged.

\section{References}

1. B. A. Wisena, A. Daryanto, B. Arifin, R. Oktaviani. Sustainable development strategy and the competitiveness of Indonesian palm oil industry. Int. J. Managerial Studies Res, 2, 10, (2014), pp. 102-115.

2. N. F. Ishak, A. L. Ahmad, S. Ismail. Feasibility of anaerobic co-composting empty fruit bunch with activated sludge from palm oil mill waste for soil conditioner. Journal of Physical Science, 25, 1, (2014), pp. 77-92.

3. I. A. Udoetok. Characterization of ash made from oil palm empty fruit bunches (OEFB). International Journal of Environmental Sciences, 3, 1, (2012).

4. F. E. Ekpo, E. N. Okey, M. E. Asuquo. Effect of oil palm empty fruit bunches (OPEFB) amendments in crude oil polluted soil on germination and growth performance of white mangrove species (Lagunculariaa racemosa). European Environmental Sciences and Ecology Journal, 1,1, (2014).

5. M. R. Gidde, A. P. Jivani. Waste to wealth - potential of rice husk in India. Proceedings of the International Conferences of Cleaner Technologies and Environmental Management PEC, Pondicherry, India. January 4-6, (2007). pp. 586590.

6. I.A.W. Tan, A.L. Ahmad, B.H. Hameed. Preparation of activated carbon from coconut husk: Optimization study on removal of 2,4,6-trichlorophenol using response surface methodology. Journal of Hazardous Materials 153, (2008) pp. 709-717. Elsevier.

7. S. Nandan, Bijoy, PK Abdul Azis. Pollution indicators of coconut husk retting areas in the Kayals of Kerala. International journal of environmental studies, 47,1, (1995): pp. 19-25.

8. B. Leena, S. Viveka. Effect of coconut husk retting on three backwater regions along the southwest coast India. Terrestrial and Aquatic Environmental Toxicology. (2009) pp. 62-64. Global Science Books.

9. M. V. Maduwar, R. V. Ralegaonkar, S. A. Mandavgane. Application of agro-waste for sustainable construction materials: A review. construction and building materials, 38, (2012) pp. 872-878.

10. I. Mazov, B. Khaydarov, D. Suvorov, T. Yudintseva, D. Kuznetsov, A. Yudin. Cement-free binders for radioactive waste produced from blast-furnace slag using vortex layer activation technology. MATEC Web of Conferences 96, 00011, (2017). doi: 10.1051/matecconf/20179600011. EDP Sciences. 
11. S. D. Halim, E. Rainer, C. Ryantonius, B. Panandito, D. Wardoyo, M. R. Fahlevy, I. S. Darma. The use of hazardous sludge solidification and green-lipped mussel shells in cementitious material: a case study of NGCC power plant of priok. MATEC Web of Conferences 147, 01008, (2018). EDP Sciences.

12. O. Gencel, C. Ozel, F. Koksal, E. Erdogmus, G. Martínez-Barrera, W. Brostow. Properties of concrete paving blocks made with waste marble. Journal of Cleaner Production 21, (2012), pp. 62-70. Elsevier.

13. S. E. Wallah. Drying shrinkage of heat-cured fly ash-based geopolymer concrete. Modern Applied Science 3.12, (2009), p. 14.

14. K. Nishikant, A. Nachiket, I. Avadhut, A. Sangar. Manufacturing of concrete paving block by using waste glass material. International Journal of Scientific and Research Publications. 6. 6, (2016), pp. 61-77.

15. J. Torkaman, A. Ashori, A. S. Momtazi. Using wood fiber waste, rice husk ash, and limestone powder waste as cement replacement materials for lightweight concrete blocks. Construction and building materials, 50, (2014), pp. 432-436.

16. F. Pacheco-Torgal, Y. Ding, S. Jalali. Properties and durability of concrete containing polymeric wastes (tyre rubber and polyethylene terephthalate bottles): An overview. Construction and Building Materials, 30, (2012), pp. 714-724.

17. S. Akçaözoğlu, C. D. Atiş, K. Akçaözoğlu. An investigation on the use of shredded waste PET bottles as aggregate in lightweight concrete. Waste management, 30, 2, (2010), pp. 285-290.

18. V. W. Tam, C. M. Tam. A review on the viable technology for construction waste recycling. resources, conservation and recycling, 47, 3, (2006), pp. 209-221.

19. B. Sulaiman, A. N. Bambang, H. Purnaweni, M. Lutfi. The effect of mangrove on fish catch using belat at Teluk Pemedas and Sanipah of Kutai Kartanegara regency, east Kalimantan province, Indonesia. E3S Web of Conferences. 31, 08029, (2018).

20. National Standardization Agency of Indonesia. SNI 03-0691-1996 concrete brick (paving block). (1996) (in Indonesian).

21. National Standardization Agency of Indonesia. SNI 15-2094-2000 solid brick for the wall. (2000) (in Indonesian).

22. I. Ivan, I. Benenson, B. Jiang, J. Horak, J. Hawort, T. Inspektor. Geoinformatics for intelligent transportation. (2014), pp. 82-83. Springer.

23. M. Lutfi. The effect of gravitational field on brachistochrone problem. Journal of Physics: Conference Series. 1028, 012060, (2018). IOP Publishing. 